\title{
Türkiye'de çevirinin toplumsal görünürlüğü ve gelişiminde çeviri derneklerinin rolü
}

\section{Güldane Duygu SEYMEN1}

\section{Aslı SELCEN ASLAN2}

\begin{abstract}
APA: Seymen, G. D.; Selcen Aslan, A. (2019). Türkiye'de çevirinin toplumsal görünürlüğü ve gelişiminde çeviri derneklerinin rolü. RumeliDE Dil ve Edebiyat Araştırmaları Dergisi, (15), 377390. DOI: $10.29000 /$ rumelide.580650
\end{abstract}

\section{$\ddot{\mathbf{O} z}$}

Son dönemlerde çeviri, toplumsal değişimlerin de etkisiyle dilsel ve metinsel düzlemin ötesinde kültürel boyutuyla tartışılır hale gelmiştir. Çokkatmanlı olan kültür kavramının incelenmesi sosyolojik bir bakış açısını gerektirmektedir. Bu noktada, toplumsal ihtiyaçtan doğan çeviri eylemini, sosyolojik bağlamda ele alarak çeviriyi kuşatan etkenlerin toplumsal ağın birer parçası olduğunu vurgulayan çalışmalar yoğunlaşmıştır. Söz konusu etkenler arasında yer alan amaç, işlev ve çeviri süreci aktörleri, devingen bir toplumsal sistem içinde yer alır. Bu sistemde, çeviri edimi ve çeviri mesleğine ilişkin algı ve beklentilerin belirlenmesi ve şekillenmesinde mesleki örgütlenmenin önemli bir rolü bulunmaktadır. Öte yandan, örgütlenme mesleki açıdan kalite ve standartların oluşturulmasında ve yaygınlaştırılmasında gereklilikler arasındadır. Dernekler, bu işleyiş içinde mesleği ve alan aktörlerini temsil eden önemli kuruluşlardır. Türkiye bağlamında çeviri dernekleri, çeviri alanıyla ilgili farkındalık yaratılması, henüz meslek statüsü kazanmamış olan çevirmenliğin meslekleşme sürecinin yönlendirilmesi ve akademik çeviri eğitiminin değişen toplumsal koşullara koşut güncellenmesine katkıda bulunmaktadır. Bu çalışmada, çeviri eylemi sosyolojik bağlamda ele alınmış ve bu bağlam içinde dernekleşmenin çeviri açısından önemi ve rolü Türkiye özelinde tartışılmıştır. Çalışma kapsamında ele alınan dernekler olan Çeviri Derneği, Çeviri İşletmeleri Derneği, Çevirmenler Meslek Birliği ve Türkiye Konferans Tercümanları Derneği vizyon ve misyonları açısından değerlendirmiş ve alanın toplumsal görünürlüğü ve gelişmesi için yürüttükleri çalışmalar farkındalık yaratma, meslekleşme ve eğitim bağlamında irdelenmiştir.

Anahtar kelimeler: Çeviri dernekleri, çeviri sosyolojisi, kurumsallaşma, meslekleşme, çeviri eğitimi.

\section{The role of translation associations in turkey on the social visibility and development of translation field}

\begin{abstract}
Recently, translation has been discussed with the cultural dimension beyond the linguistic and textual plane with the effect of social changes. The study of the multilayered culture requires a sociological perspective as well. At this point, studies focusing on the sociological context in the field of translation studies have multiplied. Approaches that address translation in a sociological context emphasize that all elements surrounding the translation are parts of a social network. The purpose,

1 Dr. Öğr. Üyesi, Manisa Celal Bayar Üniversitesi, Fen-Edebiyat Fakültesi, Mütercim-Tercümanlık Bölümü (Manisa, Türkiye), duygu.seymen@cbu.edu.tr, ORCID ID: 0000000178652349 [Makale kaylt tarihi: 21.05.2019-kabul tarihi: 20.06.2019; DOI: 10.29000/rumelide.580650]

2 Dr. Öğr. Üyesi, Manisa Celal Bayar Üniversitesi, Fen-Edebiyat Fakültesi, Mütercim-Tercümanlık Bölümü (Manisa, Türkiye), asli.aslan@cbu.edu.tr, ORCID ID: 0000000160654960


The role of translation associations in turkey on the social visibility and development of translation field / G. D. Seymen; A. Selcen Aslan (p. 377-390)

\begin{abstract}
function and translation process actors take place in a dynamic social system. The professional organization plays a vital role in determining and shaping perceptions and expectations of translation and translation as a profession. On the other hand, the organization is one of the requirements in establishing and disseminating quality and standards from a professional perspective. Associations are essential organizations that represent professionals and field actors in this network. Translation associations in Turkey, raise awareness about the translation field which has not obtained the legal professional status yet, contribute to the professionalization process, contribute to translation education to update itself with changing social conditions. In this study, translation will be discussed within a sociological framework, and the importance of translation associations and their role in Turkey will be discussed in detail. Translation and Interpreting Association Turkey, Turkish Association of Translation Companies, Translators Occupation Union and The Conference Interpreters Association of Turkey will be addressed from the perspective of their vision and missions. The work they carry out for the development and social visibility of the field will be examined in the context of awareness raising, professionalization and education.
\end{abstract}

Keywords: Translation associations, translation sociology, institutionalization, professionalization, translation education.

\title{
1. Çeviri ve sosyoloji ilişskisi
}

Çokkültürlülük ve çokdisiplinlilik kavramlarıyla tanımlanan çeviri olgusu yaşamın her alanında karşımıza çıkmaktadır. Bir mahkeme salonu, bir hastane odası, bir şirket toplantısı ya da bir afet bölgesi farklı kültür ve diller arası iletişim ihtiyacının bulunduğu ortamlar olabilir. Çeviri söz konusu ortamlardaki iletişim ihtiyacını karşılayan eylemdir. Dolayısıyla, çevirinin toplumla olan içiçeliği, bu alanın dilsel ve metinsel düzlemin ötesinde değerlendirilme gerekliliğini vurgulamaktadır. $\mathrm{Bu}$ bağlamda, çeviriyi ve çevirmenin sosyal ortamını kuşatan etmenler irdelenmelidir. Editör, müşteri, işveren, kurum, çeviri araçları gibi unsurlar söz konusu sosyal ortamın bileşenleri arasındadır. Sonuç olarak, çeviri ve sosyal ağ ilişkisi çeviribilimde yeni yaklaşımları beraberinde getirmiştir. Tarihsel süreç incelendiğinde, kuramsal bağlamda dil birimlerinden metne, metinden kültür katmanlarına ve dolayısıyla sosyolojiye geçiş gözlemlenebilir. Bir başka deyişle, kuramsal açıdan çeviri etkinliğinin işlevsel ve bütünsel değerlendirilmesinin de katkısıyla disiplinin sosyo-kültürel bir temele oturduğu görülmektedir. 1990'lardaki kültür odaklı çalışmaların (Bassnett and Lefevere 1990; Snell-Hornby 2006) çeviri sosyolojisi alanının temelini hazırladığı söylenebilir. Bu alanda öne çıkan çalışmalar (Wolf 2007, 2014; Chesterman 2006, 2007; Snell-Hornby 2006; Pym 2004; Even-Zohar 1990; Hermans 2007), günümüz bilgi toplumunun ihtiyaçları bağlamında çeviri eyleminin gerçekçi yaklaşımlarla irdelenmesine ve açıklanmasına olanak sağlamıştır ve disiplinin tüm bileşenleriyle bütünsel olarak görünür olmasına katkıda bulunmuştur.

Günümüz dünyasında, teknoloji ve iletişim alanlarındaki gelişmeler, bilgi üretimini ve yayllımını hızlandırmıştır. Toplumlar sürdürülebilir sosyal, kültürel ve ekonomik kalkınma için, uluslararası toplumun ürettiği bilgiye erişebilmeli ve bu bilgiyi kullanabilmelidir. Bu noktadan hareketle, bilgi aktarımının her an ve her ortamda yapılabilir hale gelmesi, bir anlamda zamansızlaşması ve mekansızlaşması, çeviri eylemini ulusal ve uluslararası boyutta bilgi toplumunun merkezine getirmiştir. $\mathrm{Bu}$ doğrultuda, çeviri hizmeti veren ve bünyesinde çeviri birimi bulunduran kuruluşlar ve çeviri eğitimi veren kurumlar ön plana çıkmaktadır. Dolayısıyla, söz konusu kurum ve kuruluşlar çevirinin toplumsal bağlamda görünür olmasına katkıda bulunmaktadır. Öte yandan, çevirmen de toplumda bir "aracı" 
konumuna gelmiştir ve bu nedenle kaynak ve erek metinlerin sosyo-kültürel konumunun ötesinde artık çevirmenin içinde bulunduğu sosyal ağın işleyişi önem kazanmıştır (krş. Pym, 2004).

Bu çalışmanın amacı, Türkiye'de çeviri sosyal ağının önemli bir bileşeni olan çeviri derneklerinin, alanın toplumsal görünürlüğüne ve gelişimine sağladığı katkıyı somut örnekler üzerinden değerlendirmektir. Çalışmaya konu olan dernekler Türkiye'de çevirmen örgütlenmesinin en kapsamlı örneği olan Çeviri Derneği, Türkiye'deki çeviri işletmelerini çatısı altında toplayan Çeviri İşletmeleri Derneği (ÇiD), yazın çevirmenlerini temsil eden bir platform olan Çevirmenler Meslek Birliği (ÇEVBİR) ve sözlü çeviri alanında faaliyet gösteren Türkiye Konferans Tercümanları Derneği'dir (TKTD). Adı geçen derneklere ilişkin açıklamalara ve değerlendirmelere geçmeden önce dernek kavramı ve çeviri alanında dernekleşme üzerinde durulacaktır.

\section{Dernekleşme ve çeviri}

Toplum içerisindeki farklı toplulukların kendilerine özgü iletişim kalıpları ve işleyişleri bulunmaktadır. Bu farklılıklar dizge içerisinde bir birliği oluşturur (krş. Luhmann, 1995, s. 18). Dernekler sözü edilen birliğin örnekleri olarak sayllabilir. 4721 sayılı Türk Medeni Kanunu'nun 56. Maddesine göre dernek "gerçek veya tüzel en az yedi kişinin kazanç paylaşma dışında belirli ve ortak bir amacı gerçekleştirmek üzere, bilgi ve çalışmalarını sürekli olarak birleştirmek suretiyle oluşturdukları, tüzel kişiliğe sahip kişi topluluklarıdı"”. Dernekler, bir alanın sosyal sistem içinde yer edinmesine yardımcı olur. Ortak amaçlar etrafında toplanma, bilgi paylaşımı ve işbirliği içinde çalışma etkinlikleri dernekleşmenin sosyal bir eylem olduğuna işaret etmektedir. Bu yönüyle dernekler, birey, kurum ve kuruluşların sosyal ağlarını oluşturmalarında önemli role sahiptir.

Çeviri alanı açısından incelendiğinde, Türkiye'de dernekleşmenin yukarıda sözü edilen işlevlerinin yanı sıra, alanın kurumsallaşması açısından da önem taşıdığı görülmektedir. Daniel Gile, çeviribilim alanı için kurumsallaşmanın önemini şu şekilde açıklamaktadır:

Çeviri alaninda araşttrmanin kurumsallaşması teknik ve sosyolojik nedenlerden ötürü önemlidir:

İlk olarak, özellikle çeviri alanında olduğu gibi çok fazla değiskeni barındıran bir olgu söz konusu olduğunda, bir konuda araştırmanın etkin olabilmesi, çok kapsamlı çalsşmalar yapılmasını gerektirir [. . .]. İkinci olarak, bir konuda araștırmanın etkin olabilmesi araștırma sorularının belirli sorunlara ilisskin olmasl ve araştırma yöntemlerinin de mevcut araştırma ortamına uyarlanmasın gerektirir [. . .]. Üçüncü olarak, kurumsallaşmış bir çeviri alanı akademik meşruiyet aracthğıyla çevirmenlerin statüsüne katkıda bulunabilir (2012, s. 74).4

Görüldüğü üzere, çeviri alanının özerkleşmesi ve toplumsal kabulü kurumsallaşmadan geçmektedir. Alanın kurumsallaşmasında dernekleşmeye koşut olarak değerlendirilmesi gereken bir diğer unsur akademik eğitimdir. Bir toplumda bir mesleğin kabul görmesi için, o mesleğe ilişkin eğitimin olması gerekmektedir. Bu anlamda, Avrupa'da ilk çeviri bölümlerinin 20. Yüzyılın ilk yarısının sonunda kurulduğu görülmektedir (krş. Delisle ve Woodsworth, 2012, s. 255). Türkiye'de ise lisans düzeyinde çeviri eğitimine Avrupa'dan daha geç, 1980'li yılların başında başlanmıştır. Zaman içerisinde akademik bilincin oluşmasıyla ortaya çıan bütünsel bakış, çeviriyi toplumsal bir ağ içinde tartışılır hale getirmiştir. Bu bağlamda, yine aynı yıllarda çeviri alanında örgütlenmelerin oluştuğu ve derneklerin kurulduğu izlenmektedir. Tüm bu gelişmeler, çeviri alanının toplumsal kabulü ve kurumsallaşması yönünde atılan adımlar olarak değerlendirilebilir.

https://www.dernekler.gov.tr/tr/mevzuat/kanun/4721-sayili-turk-medeni-kanunu.aspx_erişim tarihi: 22.01.2019 Aksi belirtilmedikçe çeviriler tarafımıza aittir. 
The role of translation associations in turkey on the social visibility and development of translation field / G. D. Seymen; A. Selcen Aslan (p. 377-390)

Çeviriye ilişkin sözü edilen kurumsallaşma süreci birçok aktörle bağlantılıdır. Akademik birimler, işletmeler, bünyesinde çeviri birimi bulunduran kurumlar bu süreci şekillendirir ve gidişatına yön verir. Öyleyse kurumsallaşma, sosyal ağ içinde yer bulma ve kabul görme ile doğru orantıll görülebilir. Çeviriyi kültürel, sosyolojik ve bilişsel bağlamlar içinde ele alan Andrew Chesterman, çeviribilimin çalışma alanları düşünüldüğünde, kimi zaman sınırları belirsizleşen bu üç bağlamı aşă̆ıdaki şekilde açıklamaktadır:

Kültürel bağlam: değerler, düşünceler, ideolojiler, gelenekler vb. konulara odaklanır.

Sosyolojik bağlam: kişiler (özellikle çevirmenler), kişilerin gözlemlenebilir grup davranışları ve bağlı bulundukları kuruluşlara odaklanır.

Bilişsel bağlam: zihinsel süreçler, karar alma vb. konulara odaklanır (2006, s. 11).

Burada sosyolojik bağlam, çevirmenler, çevirmen grupları ve çeviriye ilişkin işletmeler ve dernekler gibi kurum ve kuruluşları kapsamaktadır. Sosyal bir varlık olan çevirmen, çeviri edimini yine sosyal bir a ğ içinde gerçekleştirir. Söz konusu sosyal ağ içindeki tüm aktörler gerek çeviri süreçlerinin işlemesi, gerekse alanın gelişmesine katkıda bulunur.

Yukarıda sözü edilen sosyal ilişkiler bütünü çeviribilimsel çerçevede bir dizge olarak ele alındığında, Itamar Even-Zohar'ın "çoğuldizge" olarak tanımladığı dizge içindeki dinamiklerin süregelen işleyişi akla gelmektedir. Even-Zohar, birbirine bağımlı hareket eden aktörlerin oluşturduğu çoğuldizgeyi şu şekilde açıklar:

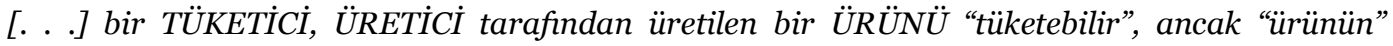
(örneğin bir "metin" gibi) üretilebilmesi için kullamlabilirliğine bir takım kuruluşlar tarafindan karar verilen ortak bir REPERTUAR olmahdır. Bu tür bir ürünün aktarlacağı bir PIYASA bulunmahdır. Sözü edilen etkenlerin hiçbiri diğerlerinden bağımsız hareket etmez ve bu ortamda gözlemlenebilir ilişkiler mevcut tablonun her yönüne doğru olabilir (1990, s. 34).

Bu birbiriyle bağlantılı ilişkiler bütünü içerisinde dernekler dizgenin önemli bir aktörü konumundadır ve çeviri ihtiyacının ortaya çıkmasından itibaren sürecin her aşamasında dolaylı veya doğrudan yer alabilirler. Derneklerin üye profilini oluşturan çevirmenler, işletmeler ve sektörün diğer çalışanları, dernek çatısı altındaki iletişim ağları sayesinde çeviri piyasasının arz talep durumunu görebilmekte, mevcut durumda bir yandan kendi konumunu diğer yandan meslektaşlarının ve paydaşlarının konumunu değerlendirebilmektedir. Bu durumda toplumsal yapıda bireylerden çok bu bireyler arasındaki iletişim ön plana çlkmaktadır. Bu noktada, dernekler çeviri alanındaki aktörlerin oluşturduğu bu birliği temsil etmektedir.

Öte yandan, aynı dizge içerisinde dernekler çevirmenin ve dolayısıyla çevirmenlik mesleğinin toplumsal statüsünün de belirleyicisi konumundadır. Bu çerçevede, sosyolojik bağlamda Bourdieu'nün alan ve sermaye kavramlarıyla çeviri eylemi arasında bağlantı kurulabilir. Bourdieu, sermayeyi “ kişinin belirli bir toplumsal alana katılımını ve bu alan içinde rekabetin getirdiği özel kazançlara ulaşmasını mümkün kılan belirli bir toplumsal arenada mevcut etkili kaynak” olarak tanımlar (içinde Arı, 2014, s. 133). Bourdieu'ye göre üç tür sermaye bulunmaktadır: Maddi kaynakları gösteren ekonomik sermaye, farklı bilgi ve beceri sahibi olma biçimlerini gösteren kültürel sermaye ve bireylerin farklı grup ve kişilerle olan ilişkileri sayesinde sahip oldukları ağı temsil eden toplumsal sermaye. Simgesel sermaye ise bu farklı sermaye tiplerinin tanınmasıyla büründüğü biçim olarak kabul edilebilir (krş. a.g.e. 95-96). 
Bu bağlamda, çeviri alanı bir "sosyal alan" olarak kabul edilirse, çevirmenin bu alan içindeki gücünü belirleyen sermayelerini5 ${ }^{5}$ oluşturması ve geliştirmesi açısından derneklerin önemli bir rol üstlendiği söylenebilir. Derneklerin çatısı altında topladığı farklı disiplin ve sektörlerden temsilciler sayesinde çevirmen sosyal sermayesini, bir anlamda sosyal ağını geliştirir. Diğer yandan, derneklerin birer bilgi paylaşımı ortamı olması çevirmenin kültürel sermayesine katkıda bulunur. Son olarak, derneklerin işbirliği ve tanıtım yoluyla sağladığı ekonomik kazanımlar ile çevirmen ekonomik sermayesini güçlendirebilir. Bilgi, beceri ve ekonomik gücü arttıkça alanda tanınması ve kendini kabul ettirmesi simgesel sermayesine işaret eder ki bu toplumsal statü ve güç açısından oldukça önemlidir.

Türkiye için düşünüldüğünde, özerk bir disiplin olarak varolabilme ve mesleki bağlamda çevirmenlere toplumsal statü kazandırma konusunda en önemli aktörlerden biri şüphesiz derneklerdir. Derneklerin bir alanda sosyal ağ oluşturma işlevi alanda işbirliğini ve bilgi paylaşımını beraberinde getirir. Bu işbirliğinin ve bilgi paylaşımının nitelikli olduğu durumlarda, mesleğin toplumda temsil edilme gücü artar. Dernekler, Douglas Robinson'ın “çeviri üzerine okuma, diğer çevirmenlerle çeviriye ilişkin konuşma, dilsel aktarım, kullanıcı talepleri, ücretlerin ödenmemesi gibi sorunları tartışma, çeviriye ilişkin dersler alma, çeviri konferanslarına katılma, alandaki teknolojik gelişmeleri takip etme” eylemlerinin gerçekleştiği yer olarak tanımladığı ortama işaret etmektedir (2012: 27). Bu anlamda dernekler, çevirmenler için sosyal ağlarını çeşitli açılardan zenginleştirdikleri birer yaşam boyu öğrenme merkezleri olarak tanımlanabilir.

\section{Türkiye'de çeviri dernekleri}

Türkiye'de çeviri alanındaki dernekleşmenin iki boyutu olduğu söylenebilir. Bunlardan birincisi dernekleşmenin akademik boyutu, ikincisi ise sektörel boyutudur. Akademi, çeviri disiplininin sosyopolitik bağlamda tanınırlığını ve kabulünü, sektör ise ekonomik bağlamda tanınırlığını ve kabulünü temsil eder. Dolayısıyla, çeviriye ilişkin nitelikli, başka bir deyişle toplumsal temsil gücü yüksek dernekler alanın sözü edilen iki kesiminin sosyal ortamını ve kesişim noktasını oluşturmaktadır.

Türkiye'de çeviri derneklerinin alandaki akademisyenlerin öncü girişimleriyle filizlendiği görülmektedir. Çeviribilim akademisyenleri alan aktörlerinin kurumsal bir çatı altında örgütlenmesine ön ayak olmuştur (krş. Eruz, 2012). Çeviri alanındaki farkındalığın disiplinin akademik nitelik kazanmasıyla oluştuğu söylenebilir. Bu doğrultuda, çevirinin toplumsal ve kültürel boyutu akademik platformda ön plana çlkmıştır.

Yukarıda sözü edilen örgütlenmenin zaman içerisinde çeviri sektörüne de yansıdı̆̆ı görülmektedir. Sektör temsilcileri kendi içlerinde birleşerek kendi örgütlenmelerini oluşturmuşlardır. Bu dayanışma, piyasa aktörlerinin alana ilişkin bilincini, bir anlamda kültürel sermayelerini geliştirmelerine katkı sağlamaktadır.

Bu bağlamda, Türkiye'de çeviri derneklerinin çeviri alanına katkısı üç başlık altında ele alınabilir: (1) çeviri alanına ilişkin farkındalığın oluşturulması (2) çevirinin meslekleşmesi (3) çeviri eğitiminin piyasa koşullarına koşut şekillendirilmesi. Bu başlıklar altında değerlendirilecek olan Çeviri Derneği, Çeviri İşletmeleri Derneği (ÇiD), Çevirmenler Meslek Birliği (ÇEVBİR) ve Türkiye Konferans Tercümanları Derneği (TKTD) alanlarında nitelikli ilk örgütlenmeler olmaları nedeniyle öncü konumundadır ve bu

5 Bourdieu'nün sosyal alan ve sermaye kavramları için bkz. Tyulenev, 2014: 171-176

\footnotetext{
Adres $\mid$ Adress 
The role of translation associations in turkey on the social visibility and development of translation field / G. D. Seymen; A. Selcen Aslan (p. 377-390)

nedenle çalışma kapsamına alınmıştır. İlgili başlıklar altında değerlendirmeye geçmeden önce, dernekler kısaca tanitılacaktır.

Çeviri Derneği, 1999 yılında alanın akademisyenleri ve dönemin önemli sektör temsilcileri tarafından kurulmuştur. Akademi ve sektör paydaşlarının bir arada bulunduğu bir örgütlenmedir. Bu yönüyle aynı zamanda geniş bir profili temsil etmektedir. Amaçları arasında "çevirinin bilimsel ve toplumsal önemini vurgulamak; kamuoyunda çeviri ve çevirmenle ilgili duyarlılık ve bilinci geliştirmek", "çevirmenlerin hak ve yükümlülüklerini ve çevirmenlik mesleğinin uygulama koşullarını ve etik ilkelerini belirlemek ve güncellemek" ve "çevirmenlerin toplumsal ve ekonomik koşullarının iyileştirilmesi yönünde çalışmalar yapmak"6 yer almaktadır. Çeviri Derneği, International Federation of Translators (FIT) üyesidir. FIT, 1953 yllında kurulmuş ve dünyada 53 ülkeden 113 çeviri derneğinin üye olduğu bir birliktir. Bu anlamda, Çeviri Derneği'nin bu birliğe üyeliği alanın uluslararası standartlarını tanıdığını ve kendi ülkesine bu standartları getirme misyonunu üstlendiğinin göstergesidir.

Çi̇D, “çeviri sektöründe üzerinde mutabakata varılmış standartların, tanımlamaların oluşturulmasında katkıda bulunmak ve Türkiye'deki çeviri işletmelerini tek bir çatı altında toplayarak, birlikte hareket etmelerine olanak sağlayacak kurumsal yapının temellerini atmak"7 amacıyla 2007 yılında kurulmuştur. $\mathrm{Bu}$ dernek, dönemin uluslararası gerekliliklerini büyük ölçüde karşılayan sektör temsilcilerinden oluşmaktadır. Her ne kadar kurucuları işletme sahibi olsa da birçoğu aynı zamanda akademi içerisinde de yer alan aktörlerdir. Bu bağlamda, sektör ortakları arasında Çeviri Derneği bulunmaktadır. Ayrıca, dernek European Union Associations of Translation Companies (EUATC) üyesidir.

ÇEVBİR, 2006 yılında kurulmuş, yayıncılık piyasası ve kitap çevirisi/çevirmenliğine yönelik faaliyet gösteren bir dernektir. Amaçları arasında "çevirmenlerin haklarının korunması, çeviri kalitesinin yükseltilmesi ve alana ilişkin etik ilkelerin yerleştirilmesi”8 bulunmaktadır. Dernek, faaliyetleri açısından ağırlıklı olarak yazın çevirmenlerini temsil etmektedir. Bu anlamda belirli bir uzmanlık alanına yönelik ilk örgütlenmeler arasındadır. 29 ülkeden 35 çevirmenler birliğini bünyesinde barındıran European Council of Literary Translators' Associations (CEATL) üyesidir.

TKTD, 1969 yılında 20 konferans tercümanı tarafından kurulmuştur. Sözlü çeviri alanının görünür hale gelmesinin 2. Dünya Savaşı sonrası Nazilerin yargılandığı Nürnberg mahkemelerine kadar uzandığı düşünüldüğünde, bu derneğin Türkiye'de çevirinin bir disiplin olarak yer bulmasından çok önce kurulmuş olması şaşırtıcı değildir. Derneğin amacı "konferans tercümanı olarak çalışanların bir araya gelmesiyle mesleğin ülke çapında tanıtımını sağlamak, çalışma koşulları ve meslek kuralları konusunda uluslararası standartlara uygun ilkeleri yerleştirmektir".9 Dernek, International Association of Conference Interpreters (AIIC) üyesidir. AIIC'nin 100 ülkeden 290o'den fazla üyesi bulunmaktadır. TKTD, diğer AIIC üyeleri gibi derneğin belirlediği etik kurallara ve mesleki standartlara uymak durumundadır. Bu kurallar ve standartlar Türkiye'de sözlü çeviri piyasasının gelişiminde önemli rol oynamaktadır.

\section{1. Çeviri alanına ilişkin farkındalığın oluşturulması}

Çeviri uygulamalarının zamanla akademik düzlemde salt bir dil aktarımının çok ötesinde alanın kendi gerçekleriyle tartışılmaya başlanması çevirinin sosyo-kültürel yapısını görünür hale getirmiştir.

\footnotetext{
6 http://www.ceviridernegi.org/amaclar.html erişim tarihi: 25 Ocak 2019

7 https://www.cid.org.tr/Kurumsal/Hedefler erişim tarihi: 25 Ocak 2019

http://cevbir.org.tr/tarihce erişim tarihi: 25 Ocak 2019

http://www.tktd.org/tktd-nedir/ erişim tarihi: 25 Ocak 2019
} 
Çeviribilimde zamanla derinleşen kuramsal çalışmaların da desteğiyle çeviri eylemini kuşatan unsurlar ele alınmış ve çeviri sürecinin pek çok aktörün yer aldığı farklı süreçleri barındıran bir bütün olduğu anlaşılmıştır (krş. Holmes 1988, Vermeer 1989, Toury 1995, Snell-Hornby 2006). Bu gelişmeler, çeviribilim alanında dil-metin-kültür-sosyoloji düzlemlerindeki dönüm noktalarını göstermektedir. Kısaca bu süreç, çeviri olgusunun doğasına ilişkin farkındalığın oluştuğuna işaret etmektedir.

Yukarıda sözü edilen gelişmelerin yansımaları Türkiye'de akademik ve sektörel boyutlarda gözlemlenebilir. Çeviri dernekleri sözü edilen farkındalığın oluşmasında önemli bir yere sahiptir. Bu noktada, Türkiye'de çeviri alanı aktörlerinin İstanbul Üniversitesi Çeviribilim akademisyenlerinin öncülüğünde ilk defa bir araya geldiği Forum: Türkiye'de Çeviri Eğitimi Nereden Nereye? toplantısı örgütlenme adına bir dönüm noktası olarak kabul edilebilir. Çeviri alanında en kapsayıcı ilk dernek olan Çeviri Derneği’nin bir dönem ikinci başkanlığını yapan işletmeci ve akademisyen Işın Bengi-Öner, bu toplantıyı çeviri disiplinindeki dönüşümlerin eğitimdeki ve piyasadaki yansımalarını görebilmek açısından önemsediğini belirtmiştir. "Dönüm noktasını oluşturan bakış açısını çevirmen, eleştirmen, araştırmacı, işveren, eğitim kurumu ve piyasa bağlamında tartışmak istiyoruz” sözleriyle toplantının alan aktörleri açısından kapsayıcılığını vurgulamıştır (1997, s. 8). 1996 yılında düzenlenen bu toplantının sağladığı bilgi paylaşımı ve işbirliği ortamının katkısıyla, birkaç yıl içinde Çeviri Derneği kurulmuştur. Dernek, akademi ve sektör işbirliği, yayıncılık ve çeviri, yaratıcı yazarlık ve çeviri, açık çeviri, çeviri odaklı terimce, mesleki yaşam gibi çeşitli konularda düzenlediği etkinlikler ile alana ilişkin farkındalığın arttırılmasına ve alanın gelişimine katkı sağlamaya devam etmektedir.

Öte yandan, Çeviri Derneği çevirinin toplumsal bir ihtiyaç olduğunun farkına varılması ve bu eylemin doğasının anlaşılması için çalışmalar yürütmektedir. Bu bağlamda öne çıkan alanlardan biri de toplum çevirmenliğidir. Toplum çevirmenliği ${ }^{10}$ özellikle farklı dil ve kültürlerden kişilerin bir arada yaşadığı toplumlarda, kişilerin toplumsal hizmetlerden faydalanmasını sağlama işlevi görmektedir. Günümüzde toplum çevirmenliğinin kapsamına "savaş, iç savaş, terör eylemleri gibi çatışma durumları ve afetlere bağlı olarak saha çevirisi ve acil durumlar da eklenmiştir” (Kurultay \& Bulut, 2012: 81). Çeviri Derneği, söz konusu durumlarda son derece hayati önem taşıyan iletişim ihtiyacının profesyonel bir koordinasyon içerisinde karşılanmasına yönelik dünyada bu alanın ilk örneği olan Afette Rehber Çevirmenlik (ARÇ) topluluğunu kurmuştur."1 $\mathrm{Bu}$ toplulukta çalışan gönüllü çevirmenler arama kurtarma, ilkyardım ve afet sonrası yardım süreçleriyle ilgili eğitim almaktadır. ARÇ’a olan ihtiyaç 1999 Gölcük depremi sonrasında yaşanan kaos ortamında açığa çıkmıştır. Bu süreçte, yardım sahalarında iletişim koordinasyonunun önemi fark edilmiş ve ARÇ bu ihtiyacı karşılamak üzere oluşturulmuştur. Topluluğa bağlı gönüllü çevirmenler, 2011 yılında yaşanan Van depremi sonrasında afet alanlarında görevlerini başarıyla yerine getirmişlerdir. Bu anlamda, ARÇ’ın toplumsal ihtiyaçların karşılanmasında bir boşluğu doldurduğu ve çevirinin önemine yönelik bir farkındalık yarattığı yadsınamaz.

Çeviri alnına ilişkin farkındalığın oluşmaya başlamasıyla birlikte piyasa aktörleri de kendi örgütlenmeleri aracılığıyla bu farkındalığa katkıda bulunmaktadır. Çevirinin uygulama sahası olan çeviri piyasası koşullarının ve piyasa işleyişindeki temel unsurların doğru anlaşılması, çeviri gerçeklerinin kavranması açısından son derece önemlidir. Günün koşullarına göre değişen piyasa modeli ve ihtiyaçları bilinmeden çeviriye ilişkin sağlıklı bir farkındalık oluşturmaktan söz etmek güçtür. Çeviri işletmeleri temsilcileri tarafından kurulan ÇìD, çeviri piyasasının işleyişi ve gereksinimlerinin belirlenmesi ve tanıtılmasında önemli rol oynamaktadır. Dernek bu anlamda, değişen dünya koşullarıyla birlikte ortaya çıkan yeni aktör ve iş tanımlarının tanıtılması ve kullanılması için çalışmalar

\footnotetext{
$10 \quad$ Ayrıntılı bilgi için bkz. Bancroft 2015; Hale 2007.

11 http://www.ceviridernegi.org/arc.html\# erişim tarihi: 02.02.2019
} 
The role of translation associations in turkey on the social visibility and development of translation field / G. D. Seymen; A. Selcen Aslan (p. 377-390)

yürütmektedir. Teknolojinin çeviri alanındaki hâkimiyeti çeviri araçlarının kullanımını yaygınlaştırmış ve her bir çeviri süreci artık çevirmen, editör, redaktör, yönetici gibi farklı aktörlerin birlikte çalıştı̆̆ı bir proje şeklini almıştır. Bu bağlamda, çiD ülke genelinde verdiği seminerlerle, çevirmen adaylarına yönelik staj programları ve şirket içi eğitimleriyle tüm bu gelişmelere ilişkin farkındalığın oluşmasına katkı sağlamaktadır. Buna örnek olarak, Derneğin 2015 yllında başlattı̆̆ı ASİP - Akademi Sektör İşbirliği Programı gösterilebilirr22. Bu program kapsamında çevirmenlik eğitimi alan kişilere yönelik hazırlanan BDÇ (Bilgisayar Destekli Çeviri) araçları, lokalizasyon, biçem kılavuzu, terminoloji vb. konulu bilgilendirme toplantıları düzenlenmektedir. Derneğin bir diğer programı olan Yönetici Okulu, bir çeviri işletmesi yönetimi için gerekli olan nitelikler ve donanımlar hakkında çalıştaylardan oluşmaktadır ${ }^{13}$. Bütün bu çalışmalar, hızla değişen toplumsal koşullarla birlikte şekillenen çeviri gerçeklerinin anlaşılması ve bunlara ayak uydurulması gerekliliğine işaret etmektedir.

Çeviri alanında toplum bilincine ihtiyaç duyulan diğer bir alan da çeviri eserlerin yer aldığı yayıncılık piyasasıdır. Çeviri eserlerin yayınlanma sürecinde ve sonrasında çevirmenlerin konumu, sorumlulukları ve hakları konusu birçok toplumda sorun olarak karşımıza çıkmaktadır. Bu sorun çoğu zaman hem mesleki hem de yasal anlamda bilgi eksikliğinden kaynaklanmaktadır. Bu noktada ÇEVBİR, söz konusu sorunlara çözüm arayan bir dernek olarak karşımıza çıkmaktadır. Dernek, özellikle yazın alanında çalışan çevirmenlerin piyasa işleyişi ve çevirmenlerin yasal hakları konularında bilinçlenmesi için çalışmaktadır. Bu doğrultuda, oluşturdukları tip sözleşmeler, basılı eser yetki belgesi, altyazıseslendirme yetki belgesi, kitap çevirmenleri ve yayınevlerine kllavuz gibi belgelerle bu alanda çalışanlara ve işverenlere destek vermektedir. Söz konusu belgeler aynı zamanda yayıncılık alanında standartlaşmanın oluşmasına önemli katkı sağlamaktadır. Öte yandan, Türkiye'de yazın çevirmenleri kimi zaman çeviri eserleriyle ilgili hukuki süreçler yaşayabilmektedir. Bu gibi süreçlerde ÇEVBİR üyelerini süreç boyunca desteklemekte ve hem kamuoyunu hem de ilgili mercileri çeviri sürecinin işleyişi ile ilgili bilinçlendirmek için çalışmaktadır¹4.

Yazılı çeviri alanında olduğu kadar sözlü çeviri de kendine özgü işleyişi olan bir alandır. Sözlü çevirinin ne olduğu, nasıl bir ortamda yapıldığı, sözlü çevirmen niteliklerinin neler olduğu hakkında yeterli bilinç düzeyine henüz ulaşılamadığı söylenebilir. TKTD, öncelikle bu konularda toplumu bilgilendirmek, sözlü çeviri alanında uluslararası standartları tanıtmak ve uygulanmasını sağlamak ve sözlü çeviri alanında profesyoneller yetiştirmek misyonlarını üstlenmiştir. 2009 yllında Davos Zirvesi'ndeki bir oturumda yapılan sözlü çeviriyle ilgili eleştiriler karşısında TKTD’nin sergilediği tutum, yüklendiği misyonları gerçekleştirdiğini kanıtlar niteliktedir. Dönemin Türkiye Başbakanı Recep Tayyip Erdoğan'ın katıldığı oturumda kendisine yeterli süre verilmediği gerekçesiyle oturum başkanıyla tartışmasının sözlü çevirisi Türk medyasında eleştirilmiştir. Çevirmenin Erdoğan'ın cümlelerini yumuşattığı ve aynı şekilde çevirmediği ileri sürülmüştür. TKTD, olayın ardından sözlü çeviri gerçeklerini ve sözlü çevirmen yükümlülüklerini anlatan bir kamuoyu açıklaması yapmıştır:

(...) sözlü çeviri, söylenenin kelimesi kelimesine aktarlması da değildir. Söylenenin içeriğini, diğer dil ve kültürün özelliklerini dikkate alarak, o dil ve kültürde ayn şekilde algılanacak biçimde aktarmaktır. Dolayısıyla bir konuşmanın "tek" bir doğru çevirisi yoktur, söylenen sözler diğer dile farkh ifadelerle de aktarlabilir: Konferans tercümanı, "anında” çeviri yaparken, o an bulabildiği en doğru karşılığı kullanır. ${ }^{15}$

https://www.cid.org.tr/Programlar/Listele?id=2 erişim tarihi: 06.02.2019

https://www.cid.org.tr/Programlar/Listele?id=6 erişim tarihi: 06.02.2019

http://www.radikal.com.tr/kultur/tercumana-zeval-olur-mu-801345/ erişim tarihi: 06.02.2019

http://www.tktd.org/anasayfa/meslek-orgutumuzun-davosla-ilgili-gelismeler-uzerine-aciklamasi/ erişim tarihi: 20.02.2019 
Bir bölümü yukarıda yer alan açıklama, sözlü çeviri süreciyle ilgili bilgi eksikliğinin altını çizerken bu sürece ilişkin toplumu doğru şekilde yönlendirme çabasını göstermektedir. Öte yandan, çevirmenin konumunu da değerlendirerek haksız eleştirilere karşı çevirmeni desteklemektedir. Yaşanan bu durum, derneğin yalnızca sözlü çeviri alanında değil genel anlamda çeviriye yönelik yanlış ve kanıksanmış algıların kıılması ve bunların doğru bilgiyle güncellenmesi için çalıştı̆̆ını göstermektedir.

\title{
3.2 Çevirinin meslekleşmesi
}

Bir işin meslek statüsü kazanabilmesi için alan aktörleri tarafından üzerinde uzlaşılmış standartların ve yeterliliklerin bulunması gerekmektedir. Diğer bir deyişle, meslek "kuralları belirlenmiş bir iştir" 16 . Geoffrey Millerson, meslekleşme sürecinin başarısını etkileyen bazı faktörleri "uygulama ve artalan bilgisinin somut temellerinin oluşturulması ve mesleki uygulamaların saydamlaştırılması, bilgi edinebilme ve uygulama firsatının bulunması, mesleğe yeni başlayanların farkındalığının geliştirilmesi, mesleğin alan dışında tanınırlığının sağlanması” olarak sıralamaktadır (1998: 10-12). Tüm bu faktörler meslekleşmenin örgütlenmeyle olan bağlantısını göstermektedir.

Bir disiplinin uygulama alanını kendine ait gerçekliklerden süzülen kuramsal bilgiyle betimleyebilmesi varlığının ispatıdır. Bir disiplin olarak çevirinin uygulama alanı ve dolayısıyla bilgisi günün koşullarına göre güncellenmektedir. Mesleği icra edenlerin bu güncellemeleri öğrenebilmesi, bir anlamda alan bilgilerini ve becerilerini güncel tutması meslekleşmenin başarısı için gereklidir. Daha önceki bölümde açılandığı üzere, alan aktörlerinin mesleki farkındalı̆̆ı ve mesleğin alan dışında tanınırlı̆̆ı da önem taşımaktadır. Öte yandan, meslekleşmenin yasal bir temelle desteklenmesi sürecin tamamlanması açısından gereklidir. Bu noktada, mesleki standartların önemi ortaya çıkmaktadır. Mesleki standartları her zamankinden daha gerekli kılan önemli bir etken küreselleşmedir. Küreselleşmeyle birlikte artan çeviri iş hacmi Türkiye piyasasında da kendini göstermiştir. Oluşan iş hacmini nitelikli bir şekilde karşılayabilen çeviri işletmeleri son dönemde sayıca artmıştır. Ancak, bu artışa rağmen ekonomik gelişmenin çevirmenlerin gelirlerine ve statülerine yeterince yansımadı $\breve{ı n ı ~ b e l i r t e n ~ T u r g a y ~ K u r u l t a y, ~ b u ~}$ durumu şu şekilde açıklamaktadır:

\begin{abstract}
Bunun nedenlerinden biri işletmeler yüksek nitelikli çevirmenden ziyade ortalama düzeyde iş görebilecek karar sorumluluğuna katılması gerekmeyen ortalama elemanlar görmeye ahşıklar. Oysa farklı nitelikte işler için farklı vasıfta elemanların istihdamı sağlansa çok daha haraketli ve doyurucu bir iş alanı oluşur çevirmenler için de. Burada kalite ölçütleri, şeffaflık önem kazanıyor. Standartlar bunun için önemli. ${ }^{17}$
\end{abstract}

Bu bağlamda, Türkiye'de meslekleşme süreçlerini yöneten kurum Mesleki Yeterlilik Kurumu'dur (MYK) ${ }^{18}$. MYK, meslek tanımlarının yapılması, mesleki yeterliliklerin ve standartların belirlenmesi görevini üstlenmektedir. Bu süreç her meslek için MYK koordinatörlüğünde alan paydaşlarıyla yürütülen çalışmalarla gerçekleşmektedir. Yasal olarak mesleğin tanınması birkaç aşamalıdır. İlk olarak "bir mesleğin başarı ile icra edilebilmesi için Mesleki Yeterlilik Kurumu tarafından kabul edilen gerekli bilgi, beceri, tavır ve tutumların neler olduğunu gösteren asgari norm"19 olan ulusal meslek standardı (UMS) belirlenir. Bu standart, mesleğin ayrıntılı olarak tanıtıldı̆̆ı ve meslek profilinin (görevler, işlemler ve başarım ölçütleri, kullanılan araç, gereç ve ekipman, bilgi ve beceri, tutum ve davranışlar) açılkandığı bir belgedir. İkinci olarak, ulusal meslek standardını temel alan ve mesleğe ilişkin bilgi,

\footnotetext{
16 http://www.tdk.gov.tr/index.php?option=com_gts\&arama=gts\&guid=TDK.GTS.5b448e69636969.89611435 tarihi: 20.02.2019

http://www.ceviriblog.com/2013/04/11/turgay-kurultay-ile-roportaj/ erişim tarihi: 20.02.2019

https://www.myk.gov.tr/ erişim tarihi: 20.02.2019

https://www.myk.gov.tr/index.php/tr/ulusal-meslek-standard-ana erişim tarihi: 20.02.2019
} 
The role of translation associations in turkey on the social visibility and development of translation field / G. D. Seymen; A. Selcen Aslan (p. 377-390)

beceri ve yetkinlikleri tanımlayan ve öğrenme, ölçme-değerlendirme amacıyla kullanılan mesleki yeterlilikler hazırlanır. Bu aşamaları geçen meslekler için yasal statü kazanmanın yolu açılmış olur. ${ }^{20} \mathrm{Bu}$ noktada, mesleki örgütlenmenin önemi bir kere daha ortaya çıkmaktadır. Örgütlenme hak arama, mesleki bilgi paylaşımı ve gelişim için kolektif bir hareket alanı sağlamaktadır. Dernekler tam olarak bu ortamı sunar.

Türkiye'de derneklerin çevirmenliğin meslekleşme sürecinde aktif ve öncü rol oynadığı görülmektedir. Çeviri Derneği, ÇiD, ÇEVBİR ve TKTD çeviri alanında ve ilgili oldukları uzmanlık alanlarında mesleki ve etik ilkelerin oluşturulması ve uygulanması için kendi içlerinde ve gerektiğinde işbirliği içinde çalışmaktadır. Ancak, kapsayıcı ve yasalaşmaya dönük çalışma Çeviri Derneği’nin öncülüğünde 2007 yllında diğer çeviri örgütlenmeleri ve eğitim kurumlarıyla birlikte başlamıştır. 2011 yllında MYK ile başlatılan çevirmen standartlarını belirleme çalışması 2013 yılında Çevirmen Meslek Standardının²1 yayımlanmasıyla sonuçlanmıştır. Bu süreci yürüten Çeviri Mesleği Çalışma Grubu üniversiteler, çeviri dernekleri ve dönemin Avrupa Birliği Bakanlığı Çeviri Eşgüdüm Başkanlı̆̆ı'yla yürütülmüsstür. Mevcut durumda Çalışma Grubu çevirmen yeterliliklerini hazırlamaktadır. İşbirliği içinde yürütülen çalışmalarla, meslek alanlarına göre belirlenen yeterlilikler MYK, kamuoyu ve uzman görüşlerine sunulmaktadır. Sonrasında ise, değerlendirme ve belgelendirme süreçleri yer alacaktır.

Meslekleşmede örgütlenme ve dernekleşmenin rolü tartışlırken değinilmesi gereken bir konu da meslek etiğidir. Meslek etiği, mesleği icra eden kişilerin hak ve yükümlülüklerini kapsar. Meslek etiğinin standartlar çerçevesinde uygulanabilir olması meslekleşme düzeyini ve dolayısıyla niteliğini arttıran belirleyici faktörlerdir. Meslek etiği toplumsal ağ içinde kabul edildiği ölçüde işlevseldir. Diğer bir deyişle, üzerinde uzlaşılarak belirlenen kurallar ve standartlar yaygın olarak kullandığı zaman anlamlı hale gelir ve sistem içindeki işlevini yerine getirir.

Öte yandan, "etik bireysel bir olgudur; onu toplumsal bir olgu düzeyine çekebilmek için her bireyin etik olgusunu içselleştirmesi gerekir” (Eruz, 2012). Örneğin, elinde kaynak metin olarak on sayfalık boşanma ilamı olan bir müşterinin çeviri ihtiyacı erek metnin sunulacağı merciye ve metnin göreceği işleve göre farklılık gösterebilir. Bu örnekte erek metin yalnızca tarafların boşandığını belirten birkaç cümleden oluşabilir. Bu durumda, ücret farklılaşacaktır. Çevirmenin müşterisinin ihtiyacı doğrultusunda metin üretmesi çeviri etiğini içselleştirdiğini gösterir.

Dernekler mesleki etik kuralların tartışıldığı, oluşturulduğu ve uygulandığı ortamlardır. Bu nedenle, örgütlenmeler bireyin öznel olan etik anlayışını toplumsal bir sorumluluk haline dönüştürebildiği yerler olarak düşünülebilir. Bu yazıda ele alınan çeviri dernekleri alanlarında üyesi oldukları uluslararası örgütlenmeler yoluyla belirlenmiş olan mesleki ve etik normların ülkemizde de uygulanması için çalışmaktadır. Bu durumda, ilgili derneklere üyelik bu normların uygulayıcısı ve denetleyicisi olma sorumluluğunu da beraberinde getirmektedir. Örneğin, Çeviri Derneği üyesi olduğu FIT’in belirlediği "Code of Professional Practice"22 belgesindeki standartları kabul etmiştir ve bu derneğin üyeleri bu kuralların doğal uygulayıcısıdır. Bu konuya TKTD’nin de son derece titizlikle yaklaştığı görülmektedir. Dernek, yetkinlik, gizlilik, eşitlik, profesyonellik ve tarafsızlık ilkelerini meslek ilkeleri olarak benimsemiştir. Üyeliğe kabulde çevirmen bu ilkeleri uygulayacağını taahhüt ettiği bir yemin töreni düzenlenir. Bunun yanısıra, sözlü çeviri öncesinde, sırasında ve sonrasında çevirmen tutum ve davranışlarını yönlendiren "kabin adabı" adı altında belirlenmiş olan kurallara tüm üyelerin uyması

\footnotetext{
$20 \quad$ Bu konuda daha ayrıntılı bilgi için bkz. Uysal, 2017.

21 http://portal.myk.gov.tr/index.php?option=com_meslek_std_taslak\&view=taslak_listesi_yeni\&msd=2\&Itemid=432 erişim tarihi: 20.02.2019

22 http://www.fit-europe.org/vault/deont/European_Code_\%2oProfessional_Practice.pdf erişim tarihi: 02.03.2019
} 
beklenir. Tüm bu uygulamalardaki amaç uluslararası mesleki standartları ve etik kuralları uygulamak ve yaygınlaştırmaktır.

Benzer şekilde ÇİD, çeviri işletmelerinin uygulayacağı mesleki ve etik kuralları belgelendirmiştir. Derneğe üyelik koşulu olarak bu kurallara uyulması beklenmektedir. Derneğin etik kurulu işletmeci, akademisyen ve çevirmenlerden oluşmaktadır. Bu anlamda mesleğe kâr amacının ötesinde bütünlüklü bir bakış sergilenmektedir.

\section{3. Çeviri eğitiminin güncellenmesi}

Türkiye'de çeviri alanında dernekleşmenin alanın akademisyenlerinin girişimleriyle başladığı belirtilmişti. Bu durum, örgütlenme bilincinin ve çevirinin meslekleşme sürecinin çeviri eğitimi ile olan yakın ilişkisini göstermektedir. Sözü edilen ilişki karşılıklı kazanımları beraberinde getirmektedir. Çevirinin meslekleşme sürecinde önemli dönüm noktalarından olan çevirmen standartlarının ve yeterliliklerin oluşturulmasında akademisyenler öncü ve belirleyici konumda yer almıştır. Bu çalışmaların getirilerinin piyasa koşulları kadar çeviri eğitimi içeriğini de şekillendirmesi umulan bir sonuçtur. Belirlenen çevirmen yeterlilikleri bu yeterlilikleri karşılayacak çevirmenler yetiştirme amacını da beraberinde getirmektedir. Bu durumda, meslekleşme sürecinin başlamasıyla, var olan eğitim standartlarını ve içeriğini yeni beklentilere göre güncelleme ihtiyacı doğmuştur. Diğer bir deyişle, çeviri eğitimiyle kazandırılmak istenen bilgi, beceri ve yetkinlikler çevirmen yeterlilikleriyle uyum içinde olmalıdır.

Öte yandan, çeviri dernekleri uygulama alanlarındaki standartlar ve gerekliliklerle ilgili bilgilendirme ve bilinçlendirme çalışmaları yürütmektedir. Konuyla ilgili verilebilecek en somut örneklerden biri çi̇’in daha önce sözü edilen ASİP programıdır. ÇİD, bu programın 2017-2019 dönemi için çeviri kalitesi ölçme ve değerlendirme, çeviride pazarlama, terimlik kullanımı, bilgisayar destekli çeviri teknolojileri ve yerelleştirme gibi konularda sunumlar hazırlamıştır. Programın konu başlıklarını Türkiye genelindeki çeviri bölümlerine göndererek gelen talepler doğrultusunda bilgilendirme toplantıları gerçekleştirmektedir. Bu toplantılar akademinin sektörün ihtiyaçlarını anlaması ve eğitim içeriklerini bu doğrultuda düzenlemesi açısından son derece önemlidir. Öte yandan, sektör temsilcileri de bu buluşmalar sayesinde, akademinin amacının salt piyasa beklentilerini karşılamak olmadığını, bunun ötesinde alan kültürüne sahip, etik anlayışı olan, soyut ve bütünsel düşünebilen ve yaşam boyu öğrenmeyi içselleştirmiş bireyler yetiştirme amacının akademinin temel amacı olduğu anlama firsatı bulmaktadırlar. Dolayısıyla, alanın iki ayağında bu sayede birbirini anlama ve öğrencilere daha verimli ortam sunabilme fırsatı doğmaktadır.

Söz konusu ortamın çeviri eğitimine somut yansıması olarak müfredatların günün gerekleri doğrultusunda güncellendiğini görmekteyiz. Örneğin, birçok bölüm imkânları ölçüsünde alandaki gelişmeleri dikkate almaktadır. Çeviri teknolojileri, teknik metin yazarlığı, metin düzenleme ve son okuma, çeviride proje yönetimi ve terimce yönetimi gibi derslerin öğrencilere sıklıkla sunulduğu görülmektedir.

ÇEVBİR de çeviri eğitimine katkıda bulunacak çalışmalar yürütmektedir. Düzenlediği çeviri atölyelerinde öğrencilere farklı uzmanlık alanlarında çeviri uygulamaları yaptırtmakta, bu alanlardaki çeviri süreçlerini saydamlaştırmaktadır. Çevirmen etiği ve hakları konulu çalıştaylar düzenleyerek öğrencileri yayıncılık alanında bilgilendirmektedir. Buna koşut, çeviri ve yayıncılık, çevirmen kimliği ve çeviri etiği ve çeviri editörlüğü gibi dersler müfredatlarda yer almaktadır. 
The role of translation associations in turkey on the social visibility and development of translation field / G. D. Seymen; A. Selcen Aslan (p. 377-390)

Sözlü çeviri alanında TKTD hazırladığı atölyelerle öğrencilere konferans ortamının koşullarında sözlü çeviriyi deneyimleme firsatı sunmaktadır. Ayrıca dernek üyeleri üniversitelerde alan uzmanı olarak ardıl çeviri ve eşzamanlı çeviri gibi dersler vermektedir. Bu dersler sayesinde öğrenciler alanın uygulama esaslarını da tanımaktadır. Bu konuda alan uzmanlarıyla çalışmanın bir diğer katkısı üniversitelerin fiziki koşullarını ve teknik donanımlarını standartlar doğrultusunda geliştirmeleridir. Örneğin, sözlü çeviri derslerinin konferans ortamını karşılayan koşullarda yapılması için sözlü çeviri laboratuvarları kurulmakta ya da mevcut laboratuvarlar güncellenmektedir.

Üniversiteler, çeviri derneklerinin bilgilendirme ve bilinçlendirme çalışmaları açısından verimli bir ortam ve insan potansiyeli sunmaktadır. Öğrenciler ve eğitimciler, nitelikli üye sayısının artması ve dolayısıyla örgütlenmenin güçlenmesi ve sesini duyurması açısından önemli birer kaynaktır. Çeviri Derneği'nin çeviri öğrencilerini aday üye olarak kabul etmesi, meslek bilincinin ve örgüt bilincinin tabana yayılması için atılan önemli bir adımdır.

\section{Değerlendirme ve sonuç}

Bu çalışmada, çeviri alanında dernekleşmenin önemi alan farkındalığı, meslekleşme ve eğitim konuları bağlamında ele alınmıştır. Elde edilen veriler çevirinin sosyal bir eylem olduğunu ve dolayısıyla sosyal ilişkiler ağı içinde gerçekleştiğini ortaya koymaktadır. Bu bakış açısı, çeviribilimde 'sosyolojik dönüşüm' olarak adlandırılan sürecin bir sonucu olarak görülebilir. Bu bağlamda, çeviri sürecine dâhil olan aktörlerin rolleri ve önemi görünür hale gelmiş, çeviri eylemi gerek çeviri gerçekleştiren ve kaçınılmaz olarak toplumsal bütünün bir parçası olan bireylerin gerekse çeviri süreciyle ilişkili ve birçok aşamada belirleyici konumdaki sosyal kurumların birbiriyle ilişki içerisinde olduğu bir sistem içinde gerçekleşmektedir. Bu nedenle, her çeviri süreci sosyal bir bağlam içinde ele alınmalıdır (Wolf 2014: 10). Çeviri, toplumsal ağ içinde farklı aktörleri bir araya getiren ve bu aktörler arasında işbirliği gerektiren bir eylemdir. Bu eylem sosyal dizgede bir alan olarak düşünüldüğünde, çevirmen bu dizgede güç ve statü için mücadele eden bir aktördür. Bilgi paylaşımı, işbirliği ve dayanışma ortamı bu mücadelenin başarısı için gereklidir. Örgütlenmeler sayesinde çevirmen sosyal, kültürel ve ekonomik sermayesini geliştirme firsatı elde eder. Bütün bunlar çevirinin meslek olarak statüsünü güçlendirebilir. Bu noktada dernekler mesleğin toplumsal temsili ve kabulünde önemli bir rol oynamaktadır. Dernek çatısı altında bir araya gelen alan temsilcileri meslekleriyle ilgili sorunları tartışır, bu sorunlara çözüm yolları arar, örgütlenme bilincini yaygınlaştırmaya çalışır. Bir anlamda bu birliktelik mesleğe sahip çıkma ve haklarını ararken sesini daha yüksek duyurma demektir.

Türkiye'de henüz yasal anlamda meslek statüsü bulunmayan çevirmenlik mesleği açısından dernekleşmenin önemi çok daha fazladır. Çeviri derneklerinin çeviri alanına ve çevirmenlik mesleğine katkıları alana ilişkin farkındalık yaratma, meslekleşme ve çeviri eğitiminin güncellenmesi konularında somuttur. Bu üç konu yürütülen çalışmalar açısından birbiriyle iç içedir. Çeviri alanının toplum tarafından tanınması mesleki statü kazanmasında ilk adım olarak görülebilir. Bu bağlamda dernekler seminerler, eğitim programları, çalıştaylar ve tanıtımlarla alanla ilgili aktörler arasında etkileşimin önünü açmaktadırlar. Bu etkileşim, alanın güncel gelişmelerini ve gerekliliklerini hem ulusal hem de uluslararası boyutta takip edebilme olanağı sunmaktadır. Dernekler, uluslararası paydaşları sayesinde meslekleşmede standartlaşmanın öneminin farkında olarak Türkiye'de meslekleşme sürecini başlatan kurumlardır. Bu amaçla, dernekler öncülüğünde çevirmen meslek standartları oluşturulmuştur ve yeterlilikler üzerinde çalışılmaktadır. Mesleki standartlar ve yeterlilikler akademik çeviri eğitimi veren kurumlar açısından da son derece belirleyicidir. Akademinin temel amacı alan kültürüne sahip nitelikli bireyler yetiştirmektir. Uygulama alanı açısından düşünüldüğünde, bu yeterliliklerin ölçme 
değerlendirme sürecinde çeviri eğitimi almış bir kişinin başarılı olması beklenir. Dolayısıyla, eğitim kurumlarının eğitim içeriklerini bu yönde güncellemesi ve geliştirmesi ihtiyacı doğmuştur. Mevcut durumda, üniversiteler ve çeviri dernekleri bu ihtiyacın karşılanması için işbirliği içinde çalışmaktadır.

Eğitim açısından yukarıda sözü edilen güncelleme ve geliştirme toplumsal roller, mesleki görev ve sorumluluklar konularında bilinçlendirmeyi de içermelidir. Bir anlamda çeviri piyasasında uzmanlaşmanın gerektirdiği bilgi ve becerinin farkında olan bireyler yetiştirmeye odaklanılmalıdır (krş. Kiraly, 1995: 113-114). Günümüz gereklilikleri açısından bakıldığında, bu tür bir eğitimin alan kültürünü aşılayan, teknolojiyle iç içe, piyasa koşullarını yansıtabilen ve mesleki ve etik standartları uygulamayla birleştirebilen nitelikte olması gerekmektedir.

Sonuç olarak, toplumun her alanında hızlı değişim, bilgi toplumu olmanın bir sonucudur. Kültürlerarası iletişimin odağında olan çeviri alanın da her geçen gün yeni gelişmeler ortaya çıkmaktadır. Bu gelişmelere ayak uydurabilmek toplumsal ağ içerisinde yer edinebilmek ve bu yeri koruyabilmek için elzemdir. Türkiye'de çeviri dernekleri bu anlamda çevirmenlik mesleğinin anlaşılması, yasal kabulü ve akademik gelişimi için kilit roldedir.

\section{Kaynakça}

Arı, S. (2014). Çeviri Sosyolojisi. İstanbul: Aylak Adam.

Bancroft, M. A. (2015). 'Community Interpreting: A profession rooted in social justice', içinde Mikkelson, H. ve Jourdenais, R., (Ed.). The Routledge Handbook of Interpreting, (s. 217-235). London and New York: Routledge

Bassnett, S., ve Lefevere, A. (Ed.). (1990). Translation, History and Culture. London: Pinter.

Chesterman, A. (2006). Questions in the Sociology of Translation. J. F. Duarte, A. A. Rosa ve T. Seruya, (Ed.). Translation Studies at the Interface of Disciplines, 68, 9-29.

Chesterman, A. (2007). Bridge Concepts in Translation Sociology. M. Wolf ve A. Fukari, (Ed.). Constructing a Sociology of Translation, 74.

Delisle, J. ve Woodsworth J. (Ed.). (2012). Translators through History. Amsterdam, Philadelphia: John Benjamins Publishing Company.

Eruz, F. S. (2012). Avrupa Birliği Bakanlığı Çeviri Platformu. Çeviri Derneği ve Türkiye'de Çevirmenlik Mesleğinin Statüye Kavuş(a)ma(ma)sı Üzerine On Üç Yıllık Gel Gitli Bir Öykü, (s. 17-23). İstanbul.

Even-Zohar, I. (1990). Poetics Today. Polysystem Studies, 11. (2018, Mayls 10), erişim adresi: http://www.tau.ac.il/ itamarez/works/books/Even-Zohar_1990--Polysystem\%20studies.pdf

Gile, D. (2012). Institutionalization of Translation Studies. In L. V. Yves Gambier (Ed.), Handbook of Translation Studies (s. 73-80). John Benjamins Publishing Company.

Hale, S. B. (2007). Community Interpreting. Basingstoke, New York: Palgrave Macmillan.

Hermans, T. (2007). Translation, irritation and resonance. M. Wolf ve A. Fukari, (Ed.). Contructing a Sociology of Translation, s. 57-79.

Holmes, J. S. (1988). The Name and Nature of Translation Studies. Translated!: Papers on Literary Translation and Translation Studies, s. 66-80.

Kiraly, D. C. (1995). Pathways to Translation: Pedagogy and Process. Kent: Kent State University Press.

Kurultay, T. (2013, Nisan 11). Turgay Kurultay ile Röportaj. (S. Kobya, röportajı yapan) erişim adresi: http://www.ceviriblog.com/2013/04/11/turgay-kurultay-ile-roportaj/

Kurultay, T. ve Birkandan, İ. (Ed.). (1997). Forum: Türkiye'de Çeviri Eğitimi: Nereden Nereye? İstanbul: Sel Yayıncılı. 
The role of translation associations in turkey on the social visibility and development of translation field / G. D. Seymen; A. Selcen Aslan (p. 377-390)

Kurultay, T. ve Bulut, A. (2012). Toplum Çevirmenliğine Yeniden Bakışta Afette Rehber Çevirmenlik (ARÇ). $\dot{I} . \ddot{U}$. Çeviribilim Dergisi(6), s. 75-102.

Luhmann, N. (1995). Social Systems. J. Bednarz ve D. Baecker, Trans. California: Stanford University Press.

Millerson, G. (ilk basim 1964, yeniden basim 1998). The Qualifying Associations: A Study in Professionalization. London: Routledge.

Pym, A. (2004, Ocak 10). Online Publications. On the Social and Cultural in Translation Studies. (2018, Mayıs 12), erişim adresi: usuaris.tinet.cat: http://usuaris.tinet.cat/apym/online/research_methods/sociocultural.pdf

Robinson, D. (2012). Becoming a Translator: An Introduction to Theory and Practice of Translation. Routledge.

Snell-Hornby, M. (2006). The Turns of Translation Studies. New Paradigms or Shifting Viewpoints. Amsterdam: John Benjamins.

Toury, G. (1995). Descriptive Translation Studies and Beyond. Amsterdam: John Benjamins Publishing.

Tyulenev, S. (2014). Translation and Society: an Introduction. New York: Routledge.

Uysal N. M. (2017). Çevirmenlikte Meslekleşme ve Çevirmen Sertifikasyonu. Ankara: Gece Kitaplığı.

Vermeer, H. J. (1989). Skopos and Commission in Translational Action. In A. Chesterman (Ed.), The Translation Studies Reader s. 173-189. Oy Finn Lectura Ab.

Wolf, M. (2007). Introduction. The Emergence of a Sociology of Translation. M. Wolf ve A. Fukari, (Ed.). Constructing a Sociology of Translation, 74, s. 1-36.

Wolf, M. (2014). The Sociology of Translation and its "Activist Turn". C. V. Angelelli, (Ed.). The Sociological Turn in Translation and Interpreting Studies, 66, s. 7-23. 